\title{
Population trend and distribution of the Vulnerable common hippopotamus Hippopotamus amphibius in the Mara Region of Kenya
}

\author{
Erustus M. Kanga, Joseph O. Ogutu, Han Olff and Peter Santema
}

\begin{abstract}
The common hippopotamus Hippopotamus amphibius can significantly influence the dynamics of ecosystems and engender serious conflicts with people but, in Kenya, one of the species strongholds, it has been little studied or monitored. We surveyed the hippopotamus population in the Masai Mara National Reserve and the adjoining pastoral ranches in 2006 using foot counts along $155.3 \mathrm{~km}$ of the main rivers. We counted 4,170 hippopotamuses in 171 schools. Comparisons with earlier surveys suggest that this population increased by $169.6 \%$ between 1971 and 1980 within the reserve and, although it did not increase within the reserve during 1980-2006, it increased by $359.4 \%$ outside the reserve during this period against a background of deteriorating habitat conditions. The overall density in 2006 was 26.9 hippopotamuses $\mathrm{km}^{-1}$ of river, equivalent to a biomass of $26,677 \mathrm{~kg} \mathrm{~km}^{-1}$ of river. The ratio of calves to 100 adults was 9:100 inside the reserve, 10:100 outside the reserve and 6:100 along tributaries of the Mara River, implying that the population is either increasing or that its spatial distribution is being compressed because of range contraction. The apparent increase in the hippopotamus population contrasts with marked contemporaneous declines in the populations of most other large mammalian herbivore species in the Reserve. We discuss possible reasons underlying the increase in the hippopotamus population.
\end{abstract}

Keywords Climatic variability, Hippopotamus amphibius, Kenya, land-use change, Masai Mara, population dynamics

\section{Introduction}

The common hippopotamus Hippopotamus amphibius 1 is a semi-aquatic artiodactyl of sub-Saharan Africa (Kingdon, 1979; Eltringham, 1999) and, historically, was

ERustus M. KANGA (Corresponding author) Kenya Wildlife Service, P.O. Box 40241, Nairobi, Kenya, and Centre for Ecological and Evolutionary Studies, University of Groningen, Postbus 14, 9750 AA Haren, The Netherlands. E-mail ekanga@kws.go.ke

Joseph O. OGUTU International Livestock Research Institute, Nairobi 00100, Kenya, and Universitaet Hohenheim, Institut für Pflanzenbau und Gruenland, Stuttgart, Germany

Han Olff and Peter Santema Centre for Ecological and Evolutionary Studies, University of Groningen, Haren, The Netherlands

Received 11 September 2009. Revision requested 30 November 2009. Accepted 4 June 2010. widely distributed throughout the region (Eltringham, 1999; Feldhake, 2005; Lewison \& Oliver, 2008). Five evolutionary units have been described based on morphological differences (Ansell, 1971; Grubb, 1993; Eltringham, 1999) but only three of these are genetically different (Okello et al., 2005).

The range of the hippopotamus has become increasingly restricted in recent decades, a contraction that has been accompanied by substantial declines in abundance, with the most recent estimates suggesting population declines of 720\% during 1996-2004 (Eltringham, 1999; Lewison \& Oliver, 2008). Although the causes of these declines are documented and well understood (habitat loss, exploitation and conflicts with people), they continue to operate and appear unlikely to be eliminated in the near future, amplifying the need to develop effective conservation measures for the hippopotamus.

Recent estimates suggest that c. 125,000-148,00o hippopotamuses currently occur in fragmented populations in rivers, lakes and other wetlands of eastern, western and southern Africa (Oliver, 1993; Lewison \& Oliver, 2008). Of the 36 countries where the common hippopotamus is known to occur, 20 have confirmed declining populations, seven have populations of unknown status, nine have stable populations and three (Algeria, Egypt and Mauritania) have experienced recent extinctions (Lewison \& Oliver, 2008). Based on the estimated global population, coupled with intensifying threats of poaching for meat and ivory (Weiller et al., 1994; Williamson, 2004; Conservation, 2006), progressive habitat loss and persecution because of conflicts with people, the hippopotamus was categorized as Vulnerable on the IUCN Red List in 2006 (Lewison \& Oliver, 2008).

Despite its Vulnerable status and ecological significance, and rising conflicts with people, the hippopotamus has not been well studied or monitored in many parts of its range, including Kenya where the species has been officially protected since the 1920 (Kenya Game Department, 1953). Monitoring is necessary to understand the factors underpinning population dynamics and hence to develop an understanding of how the hippopotamus influences, and is influenced by, changes in riparian habitats (Field, 1970; Thornton, 1971; Lock, 1972; Eltringham, 1999) and responds to land-use changes, climate change and variability, and conflicts with humans. The paucity of data on hippopotamus population status and dynamics in Kenya is due in part to the difficulty and high costs of counting a nocturnal, semiaquatic mammal inhabiting river systems that are often 
fringed by dense riparian woodlands. It is this difficulty that has primarily limited hippopotamus population monitoring in the Mara Region of Kenya, where regular aerial monitoring and occasional ground counts of other herbivores have been conducted over the last 3 decades (Stelfox et al., 1986; Broten \& Said, 1995; Ottichilo et al., 2000; Homewood et al., 2001; Serneels et al., 2001a; Reid et al., 2003; Ogutu et al., 2009). Hippopotamuses were counted only five times in the Masai Mara River systems between 1958 and 2006 compared to $>50$ times for the other large herbivores of the Mara Region (Talbot \& Stewart, 1964; Ottichilo et al., 2000; Ogutu et al., 2009; Kenya Wildlife Service, unpubl. data; Department of Resource Surveys and Remote Sensing of Kenya, unpubl. data). These counts reveal important patterns of temporal variation in the population abundance of the hippopotamus in the area and emphasize its importance for the dynamics of the Serengeti-Mara ecosystem (Darling, 1961; Olivier \& Laurie, 1974; Karstad, 1984; Reid et al., 2003).

Our objectives in this study were to establish the current status of the hippopotamus population in the Mara Region and to investigate how the population has changed both spatially and temporally. We present data on hippopotamus population abundance in the Mara Region since 1971, and compare the temporal patterns to those of sympatric megaherbivores (elephant Loxodonta africana, black rhino Diceros bicornis and giraffe Giraffa camelopardalis) over the same period. We evaluate the effects of land use on this hippopotamus population and examine the implications of continuing changes in land use on the conservation and management of the species in the Serengeti-Mara ecosystem.

\section{Study area}

The Mara Region in south-west Kenya is bounded by the Serengeti National Park in Tanzania to the south and the Siria escarpment to the west (Fig. 1). This region forms the northernmost limit of the Serengeti-Mara ecosystem straddling the Kenya-Tanzania boundary. The ecosystem comprises several wildlife conservation administrations and conservation-pastoralist multiple land-use zones in the two countries (Sinclair \& Arcese, 1995). The c. 5,500 km² Mara includes the c. $1,530 \mathrm{~km}^{2}$ Masai Mara National Reserve and the adjacent pastoral ranches of Koyiaki, Olkinyei, Siana, Lemek and Ol Chorro Oiroua with a combined total of c. 4,000 $\mathrm{km}^{2}$. The Mara receives a mean total annual rainfall of c. $600 \mathrm{~mm}$ in the south-east rising to $1,200 \mathrm{~mm}$ in the north-west (Norton-Griffiths et al., 1975). Rainfall is bimodal, with the short rains falling during NovemberDecember and the long rains during January-June, although January and February are often dry. The vegetation is predominantly grassland, with isolated scrublands and woodlands, especially along drainage lines and on hilltops (Epp \& Agatsiva, 1980).
Several rivers and numerous streams drain the Mara but the Mara River, traversing both Kenya and Tanzania, is the only river that flows all year. The Sand, Talek and Olare Orok rivers are the main tributaries of the Mara River and are largely seasonal. The Mara River is c. $396 \mathrm{~km}$ long and its flow through the Masai Mara National Reserve and Serengeti National Park sustains a large variety of abundant wildlife, including hippopotamus, crocodile Crocodylus niloticus, wildebeest Connochaetes taurinus, Burchell's zebra Equus burchelli and Thomson's gazelle Gazella thomsoni. This wildlife assemblage supports a robust tourism industry in the Mara. However, wildlife populations there are facing many water-related problems, including increasing water shortages and declining water quality linked to expanding irrigated cultivation, unregulated water extraction, and deforestation of the Mau Forest catchments of the Mara River (Mati et al., 2005).

Marked declines in herbivore numbers in the Mara have been attributed to their progressive exclusion from pastoral ranches by land-use changes, including expansion of mechanized and subsistence agriculture and settlements, which have affected $>8 \%$ of the Mara and caused land cover changes on up to $36 \%$ of the adjoining pastoral ranches (Homewood et al., 2001; Serneels et al., 2001b; Lamprey \& Reid, 2004; Mati et al., 2005). These changes have probably intensified competition between livestock and wild herbivores on the pastoral ranches of the Mara. Moreover, settlement of the formerly semi-nomadic Masai pastoralists (Kimani \& Pickard, 1998, Western et al., 2009) and the associated intensification of land use and grazing by large numbers of livestock on the pastoral ranches has accelerated range degradation and fragmentation, including along riparian habitats. Rising temperatures and recurrent droughts (Ogutu et al., 2007) have amplified herbivore mortalities in the Serengeti-Mara ecosystem.

\section{Methods}

Ground, boat and aerial survey methods have been used to count hippopotamuses (Petrides \& Swank, 1965; Olivier \& Laurie, 1974; Marshall \& Sayer, 1976; Viljoen, 1980; Karstad, 1984; Tembo, 1987; Norton, 1988; Smart, 1990; Bhima, 1996) but accurate counts have been obtained only with ground surveys (Tembo, 1987; TAWIRI, 2001). We conducted ground counts of hippopotamus along the Mara River of Kenya, its three main tributaries and one major water pool during September-November 2006. This period was chosen because it spans the late dry season when water levels in the rivers are lowest and visibility of hippopotamuses in the water is highest.

We divided the study area into river sections using a 1:50,000 map. Three observers walked quietly along the river banks and, upon sighting individuals or groups of hippopotamuses, recorded the total number, group size and 


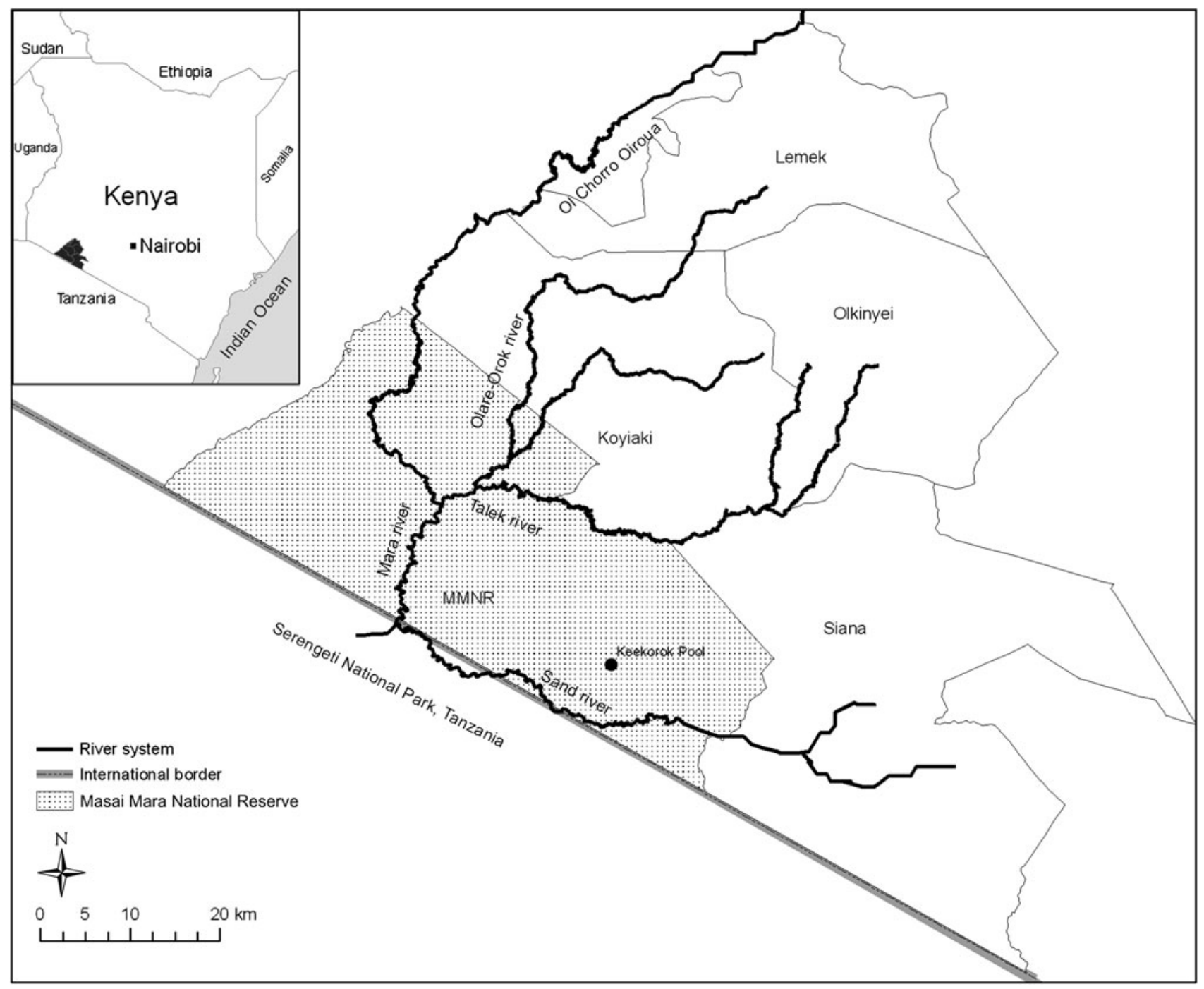

FIG. 1 Masai Mara National Reserve and the adjoining pastoral ranches, showing the Mara River and its tributaries.

number of calves, with the aid of binoculars. We distinguished calves by their small body size relative to adults and subadults. We assumed that the number of individuals counted in a group accurately represented the size of the group, based on calibration trials conducted at the Keekorok Pool with a known number of hippopotamuses. Locations of all individuals and groups were determined with a global positioning system.

We tested for differences in expected group sizes between regions of the Mara River within the Masai Mara National Reserve, pastoral ranches, and Mara River tributaries within the Reserve using a negative binomial regression model assuming a negative binomial error distribution and log link function (Edwards \& Berry, 1987). We performed multiple pairwise comparisons of expected group sizes between regions and used simulation adjustment for multiplicity. We synthesized the denominator degrees of freedom for Wald F-tests using Kenward \& Roger's (1997) method for small sample sizes. All models were fitted with the SAS procedure GLIMMIX (SAS Institute, 2006). To compare the expected percentage composition of calves inside and outside the Reserve as well as in the tributaries, we used a logistic regression assuming binomial error distribution and a logit link function. We conducted multiple comparisons of the expected percentage composition of calves across regions and adjusted the tests for multiplicity using simulation adjustment. We used $\chi^{2}$ goodness-of-fit tests to examine differences in hippopotamus densities between regions and years and analysed temporal trends in abundance by computing percentage change in abundance between consecutive counts.

\section{Results}

We counted 4,170 individuals along $155.3 \mathrm{~km}$ of the Mara River system and at one pool. As we walked long sections of the same river in a day the chances of double counting, 
although hard to eliminate entirely, were probably low. Counts made in 1971 (Olivier \& Laurie, 1974) and 1980 (Karstad, 1984) within the Masai Mara National Reserve indicated that the population increased by $169.6 \%$ during this time, i.e. a mean annual growth rate of $18.8 \%$ (Table 1 ). Between 1980 and 2006 the population did not increase within the reserve but increased outside the reserve by $359.4 \%$. The overall increase of the population in the Mara River inside and outside the reserve combined was $49.9 \%$ for this period, i.e. a mean annual growth rate of $3.1 \%$, during which new groups apparently spread upstream to the pastoral ranches (Fig. 2). Our count in 2006 represents a biomass of $26,677 \mathrm{~kg} \mathrm{~km}^{-1}$ of river, assuming a unit weight for a hippo of 1,00o $\mathrm{kg}$ (Coe et al., 1976).

The density of hippopotamuses in 2006 was 36.1 and 34.4 $\mathrm{km}^{-1}$ of river within and outside the Masai Mara National Reserve, respectively. A $\chi^{2}$ goodness-of-fit test indicated a significant difference in densities between these two stretches of the Mara River $\left(\chi_{3}^{2}=0.0001, \mathrm{P}>0.05\right)$ and over time in the Reserve $\left(\chi_{2}^{2}=0.0001, \mathrm{P}>0.05\right.$, Table 1$)$. We counted 171 groups of 1-132 individuals (Fig. 3). Although group sizes appeared large in the Mara River tributaries $(95 \%$ confidence limits $=18.7-42.5$ compared to the Mara River within, 20.2-31.7, and outside, 17.3-27.5, the Reserve), differences in group sizes among the three regions were not significant $\left(F_{2,168}=0.73 ; \mathrm{P}=0.48\right)$.

The ratio of calves to 100 adults was 9:100 (Reserve), $10: 100$ (pastoral ranches) and 6:100 (tributaries). Even though the percentage composition of calves was lower for tributaries $(95 \%$ confidence limits $=3-9 \%)$, compared to the Reserve $(7-10 \%)$ or the pastoral ranches $(8-10 \%)$, logistic regression analysis showed that the expected percentage composition of calves did not differ across regions $\left(F_{2,147}=1.87 ; \mathrm{P}=0.59\right)$ nor were there significant pairwise differences among regions.

\section{Discussion}

The hippopotamus population size reported here represents the minimum number of individuals in the part of the Mara River we surveyed. The estimated apparent annual growth rate is high, and may suggest immigration from outside, but is biologically achievable for the hippopotamus. Similar growth rates have been reported for the hippopotamus in Luangwa River in Zambia (Marshall \& Sayer, 1976) and Lundi River in Zimbabwe (O'Connor \& Campbell, 1986). This apparent growth rate could be partially attributed to protection in the Masai Mara National Reserve and the opportunity for range expansion upstream in the Mara River to the pastoral ranches. The hippopotamus typically has an adult male : female ratio of $1: 1$ (Smuts \& Whyte, 1981), compared to $1: 2$ typical of most large mammals, a gestation period of 8 months (Marshall \& Sayer, 1976; Smuts \& Whyte, 1981), which is short given its large body size, and a high fecundity of 0.55 (on average, a mature female hippo can produce a calf every 21.8 months; Laws \& Clough, 1966; Smuts \& Whyte, 1981). These factors all contribute to a high potential for rapid population increase when conditions are favourable. The high rate of apparent population growth reinforces the observation that hippopotamus populations are not often limited by diseases or predation but rather by the availability of suitable habitat and forage (O'Connor \& Campbell, 1986), with the latter being relatively abundant in less disturbed sections of the Mara (Boutton et al., 1988; Onyeanusi, 1988).

Hippopotamus density increased three-fold in the Masai Mara National Reserve, from $12.3 \mathrm{~km}^{-1}$ of river in 1971 to $36.1 \mathrm{~km}^{-1}$ of river in 2006 but with marked differences in densities between regions (Reserve $=36.1$, pastoral ranches $=$ 34.4, Talek River $=3.4$ and Olare Orok River $=48.1 \mathrm{~km}^{-1}$ of

TABLE 1 Number of hippopotamuses counted (with percentage increase compared to previous count), km of river surveyed and density of hippopotamus per km of river in the Mara Region (Figs 1 \& 2) between 1971 and 2006. Blank cells indicate absence of surveys.

\begin{tabular}{|c|c|c|c|c|c|c|c|c|c|}
\hline \multirow[b]{2}{*}{ River section } & \multicolumn{3}{|c|}{ Olivier \& Laurie $(1974)^{1}$} & \multicolumn{3}{|c|}{ Karstad $(1984)^{2,3}$} & \multicolumn{3}{|l|}{ This study (2006) } \\
\hline & No. & $\mathrm{km}$ & $\begin{array}{l}\text { Density } \\
\left(\mathrm{km}^{-1}\right)\end{array}$ & $\begin{array}{l}\text { No. } \\
\text { (\% increase) }\end{array}$ & $\mathrm{km}$ & $\begin{array}{l}\text { Density } \\
\left(\mathrm{km}^{-1}\right)\end{array}$ & $\begin{array}{l}\text { No. } \\
\text { (\% increase) }\end{array}$ & $\mathrm{km}$ & $\begin{array}{l}\text { Density } \\
\left(\mathrm{km}^{-1}\right)\end{array}$ \\
\hline $\begin{array}{l}\text { Mara River within } \\
\text { Reserve }\end{array}$ & 738 & 60 & 12.3 & $1,990(169.6 \%)$ & 74.2 & 24.1 & $1,924(-3.3 \%)$ & 53.3 & 36.1 \\
\hline $\begin{array}{l}\text { Mara River outside } \\
\text { Reserve }\end{array}$ & & & & 342 & 50.2 & 6.8 & $1,571(359.4 \%)$ & 45.7 & 34.4 \\
\hline Talek River & & & & & & & 158 & 46.1 & 3.4 \\
\hline Olare Orok River ${ }^{4}$ & & & & & & & 490 & 10.2 & 48.0 \\
\hline Keekorok Pool ${ }^{4}$ & & & & & & & 27 & & \\
\hline Total & & & & 2,332 & 124.4 & 17.1 & $\begin{array}{l}4,170 \text { ( } 49.9 \% \text {; Mara } \\
\text { River only) }\end{array}$ & 155.3 & 26.9 \\
\hline
\end{tabular}

\footnotetext{
${ }^{1}$ Counts made in July-August 1971

${ }^{2}$ Both ground and aerial counts

${ }^{3}$ Counts made in August-October 1980

${ }^{4}$ New groups established after 1982
} 


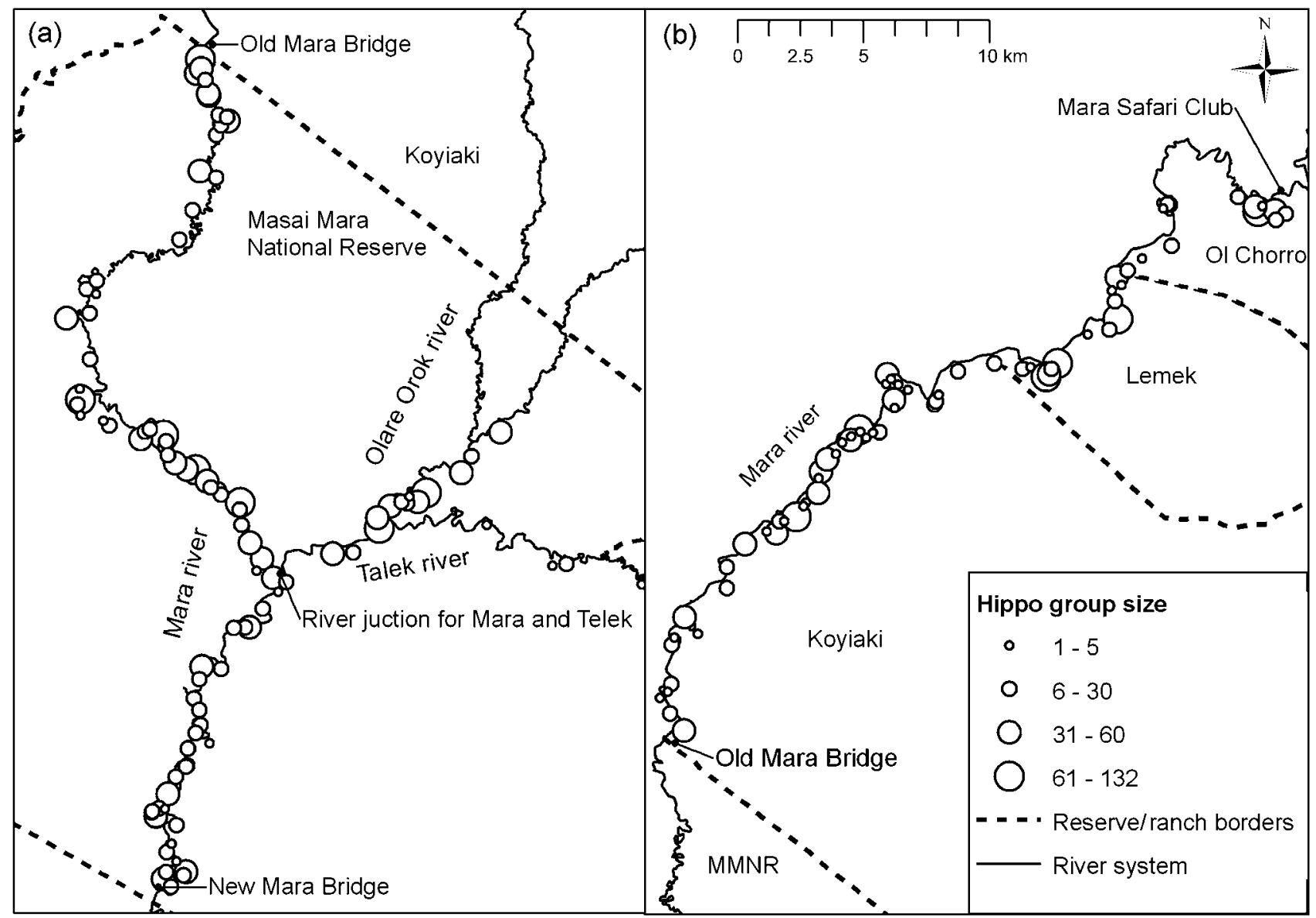

Fig. 2 Spatial distribution of hippopotamus Hippopotamus amphibius in the Masai Mara National Reserve (a) and Pastoral Ranches (b) in 2006.

river). These densities are likely to vary between seasons; elevated water levels allow groups to spread out as pools enlarge without a corresponding change in the overall hippo density.

The estimated density of $36.1 \mathrm{~km}^{-1}$ of river within the Masai Mara National Reserve is higher than the $20.2 \mathrm{~km}^{-1}$ reported for Liwonde National Park in Malawi in 1993 (Bhima, 1996) and the $21.6 \mathrm{~km}^{-1}$ reported for Luangwa River in Zambia in 1970 (Marshall \& Sayer, 1976) but similar to the $39.7 \mathrm{~km}^{-1}$ of river reported for the Luangwa River in 1983 (Tembo, 1987). However, similar direct comparisons with estimates of hippopotamus densities in other water bodies are often complicated by differences in habitat suitability (Olivier \& Laurie, 1974; Eltringham, 1999).

The similarities in expected group sizes across regions complicate identification of high-quality hippopotamus habitat; nonetheless, the relatively large group sizes in the tributaries and pastoral ranches may indicate overcrowding because there are few suitable pools (Olivier \& Laurie, 1974; Klingel, 1991; Viljoen, 1995) or compression by land-use changes, humans and their livestock. Although we counted at the end of the dry season when most surface water dries out in the Mara and the distribution of hippopotamuses is more restricted, the counts suggest that the Mara River offers more favourable water conditions for hippopotamuses during the dry season compared to its tributaries, as indicated by the moderate group sizes and wider distribution of the groups encountered, suggesting less crowding. However, land-use changes and livestock herding may be adversely affecting hippopotamuses in the section of the Mara River within the pastoral ranches and its tributaries, where hippopotamuses form relatively large groups (Mara River 17.3-31.7; tributaries 18.7-42.5).

The ratio of calves to adults represents the apparent juvenile recruitment rate, although not all calves and adults are likely to be counted in any census and some subadults grouped with adults may not have reached breeding age. However, a high calf:adult ratio is not necessarily indicative of a fast growing population because the actual rate of population growth is not only a function of this ratio but also of juvenile and subadult recruitment and mortalities. The observed ratio for the Mara hippopotamuses of $9: 100$ is almost twice the $4.8: 100$ reported for Luangwa River in Zambia in 1983 (Tembo, 1987). Although the percentage composition of calves did not differ among regions the 


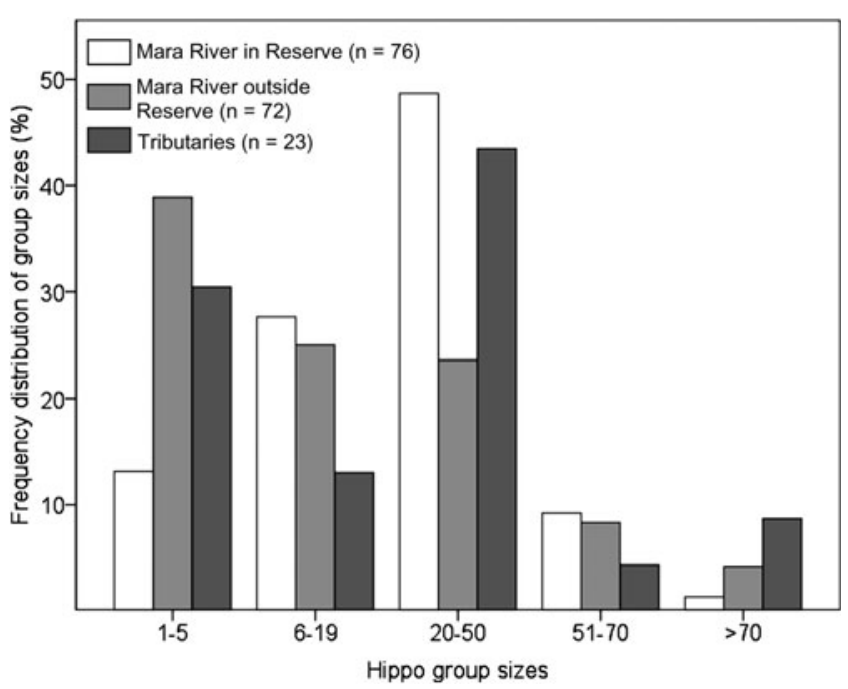

FIG. 3 Percentage frequency distribution of hippopotamus group sizes in the Mara region in 2006.

tributaries had a noticeably lower ratio, probably because of overcrowding that may depress population growth.

The numerical and spatial changes in the Mara hippopotamus population thus suggests the population is expanding but may also indicate increasing concentration of hippopotamuses in the Mara River because of contraction and compression caused by deterioration and truncation of their habitats from human activities. Moreover, if destruction of the Mara River catchments and increasing water extraction has progressively reduced overall water availability in the watershed, thus increasing the possibility of sighting hippopotamuses and yielding higher counts, then the changes are unlikely to indicate a true population increase.

The density of the hippopotamus in the Masai Mara National Reserve in 2006 was similar to that reported for 1980 , implying a stable population in the Reserve. But significant population expansion was evident in the pastoral ranches, where hippopotamus density increased five-fold from 6.8 to 34.4 hippopotamuses $\mathrm{km}^{-1}$ of river. Various authors (Sayer \& Rakha, 1974; Marshall \& Sayer, 1976; Smuts \& Whyte, 1981; O’Connor \& Campbell, 1986) have suggested that improved environmental conditions, most notably above average rainfall, improve conception and subsequent calf survival and recruitment of the hippopotamus through provision of adequate food and suitable shelter, resulting in high population growth. Our results, however, indicate that the Mara hippopotamus population increased against a background of deteriorating habitat conditions related to recurrent droughts, rising temperatures and progressive habitat desiccation (Ogutu et al., 2007), and fundamental land-use changes (Homewood et al., 2001; Serneels et al., 2001a; Lamprey \& Reid 2004; Mati et al., 2005; Ogutu et al., 2009).

The observed increase in the hippopotamus population is inconsistent with the contemporaneous declines in the populations of mammalian herbivores weighing $<1,000 \mathrm{~kg}$ in the Mara (Ottichilo et al., 2000; Homewood et al., 2001; Serneels et al., 2001a; Ogutu et al., 2009). Of the three other sympatric megaherbivores (animals weighing $>1000 \mathrm{~kg}$, Owen-Smith, 1988) in the Mara, only the elephant population has increased (Dublin, 1995; Kenya Wildlife Service, unpubl. Data); black rhino and giraffe populations have declined. The increase in elephant numbers has been attributed to an influx of elephants escaping from poachers in the Serengeti from the late 1970 s to early 1990 (Dublin \& Douglas-Hamilton, 1987). The declines in giraffe and rhino populations have been attributed to declining woodland cover (Dublin, 1995, Lamprey \& Reid, 2004), poaching (Walpole et al., 2001), habitat alteration, fragmentation and loss because of privatization of land tenure, expanding settlements, cultivation, and settlement of the formerly seminomadic Masai and consequent intensification of land use (Homewood et al., 2001; Serneels et al., 2001a; Ogutu et al., 2009). Displacement of giraffe and rhinos by pastoral livestock in the Mara might also have contributed to the declines (Mukinya, 1973; Walpole et al., 2001; Ogutu et al., 2009). The increase of the hippopotamus population on the pastoral ranches of the Mara, although probably reflecting population growth, could also reflect exclusion of hippopotamuses from parts of their former range in the adjacent pastoral areas because of progressive habitat loss and declining water levels in the Mara River. Given that the hippopotamus is a grazer whereas giraffe and black rhinos are browsers and elephant is a mixed grazer-browser, hippopotamuses could respond differentially to environmental changes compared to other megaherbivores. However, habitat degradation, fragmentation and loss due to land-use change and poaching are unlikely to be the cause of the increase in hippopotamuses because many other mammalian grazers have declined in the Mara, suggesting that contrasting feeding styles alone are insufficient to account for these differences.

It is unlikely that rainfall was responsible for the expansion of the hippopotamus population in the Mara because, despite fluctuating widely, rainfall did not increase consistently between 1971 and 2006 (Ogutu et al., 2007). A potential contributing factor could have been conversion of woodlands into grasslands in the Mara by elephants and fire (Dublin, 1995) and humans (Lamprey \& Reid, 2004) and maintenance of these grasslands by hippopotamuses and other herbivores. Together with protection in the reserve and pastoral ranches this could have offered suitable conditions for hippopotamuses to thrive. However, this does not explain why populations of sympatric herbivores declined concurrently. Given the persistent declines in numbers of the other herbivores, deteriorating habitat conditions and increasing pressure on water and other habitat resources, the high density of the hippopotamus is most likely indicative of range contraction and compression in the Mara. 
The increase in hippopotamus density in the pastoral ranches suggests these areas play an important role in sustaining the population. However, land-use changes on the ranches and destruction of forests in the Mau catchments of the Mara River will, unless regulated, restrict the distribution of the hippopotamus population, and reduction in the volume and quality of water in the Mara River and its tributaries will lead to a decline in density. This may have significant spillover effects on other mammalian grazers that are dependent on the grazing lawns maintained by hippopotamuses. Regular monitoring of the Mara hippopotamus population is therefore required to improve our understanding of the response of the species to land-use and climate changes. Because the Mara River is transnational, effective management, conservation and monitoring of the hippopotamus in the Serengeti-Mara ecosystem require close collaboration between relevant institutions in Kenya and Tanzania.

\section{Acknowledgements}

We thank Charles Matankory and Sospeter Kiambi for assistance with fieldwork and for arranging field logistics, the Kenya Wildlife Service rangers for providing security during fieldwork, wardens of the Masai Mara National Reserve and the management of the Koyiaki and Lemek pastoral ranches for allowing us unlimited access to these areas, and Dr Richard H. Lamprey for useful discussions that helped improve this article. EK was supported by the Netherlands Fellowship Programme and the University of Groningen, through the Government of Kenya, and by the Frankfurt Zoological Society.

\section{References}

Ansell, W.F.H. (1971) Order Artiodactyla. In The Mammals of Africa: An Identification Manual (eds J. Meester \& H.W. Setzer), pp. 1-84. Smithsonian Institution Press, Washington, DC, USA.

B Hima, R. (1996) Census of hippopotamus Hippopotamus amphibious (L) in the Upper Shire River, Malawi. African Journal of Ecology, 34, 83-85.

Boutton, T.W., Tieszen, L.L. \& Imbamba, S.K. (1988) Biomass dynamics of grassland vegetation in Kenya. African Journal of Ecology, 26, 89-101.

Broten, M.D. \& SAid, M. (1995) Population trends of ungulates in and around Kenya's Masai Mara Reserve. In Serengeti II: Dynamics, Management and Conservation of an Ecosystem (eds A.R.E. Sinclair \& P. Arcese), pp. 169-193. University of Chicago Press, Chicago, USA.

Coe, M.J., Cumming, D.H. \& Philipson, J. (1976) Biomass and production of large African herbivores in relation to rainfall and primary production. Oecologia, 22, 341-354.

Conservation (2006) Rebels slaughter hippos. Africa Research Bulletin: Political, Social and Cultural Series, 43, 16843A-16843C.

DARLING, F.F. (1961) An ecological reconnaissance of the Mara plains in Kenya Colony. Wildlife Monographs, 5, 1-41.
Dublin, H.T. (1995) Vegetation dynamics in the Serengeti-Mara ecosystem: the role of elephants, fire and other factors. In Serengeti II: Dynamics, Management and Conservation of an Ecosystem (eds A.R.E. Sinclair \& P. Arcese), pp. 71-90. University of Chicago Press, Chicago, USA.

Dublin, H.T. \& Douglas-Hamilton, I. (1987) Status and trends of elephants in the Serengeti-Mara ecosystem. African Journal of Ecology, 25, 19-33.

Edwards, D. \& BERRY, J.J. (1987) The efficiency of simulation based multiple comparisons. Biometrics, 43, 913-928.

Eltringham, S.K. (1999) The Hippos: Natural History and Conservation. Academic Press, London, UK.

Epp, H. \& Agatsiva, J. (1980) Habitat types of the Mara-Narok Area, Western Kenya. Unpublished Report, Series No 20. Department of Resource Surveys and Remote Sensing, Nairobi, Kenya.

Feldhake, G. (2005) Hippos: Natural History and Conservation. Voyageur Press, Stillwater, USA.

FIELD, C.R. (1970) A study of the feeding habits of the hippopotamus (Hippopotamus amphibius Linn.) in the Queen Elizabeth National Park, Uganda, with some management implications. Zoologica Africana, 5, 71-86.

GrubB, P. (1993) The Afrotropical hippopotamuses Hippopotamus and Hexaprotodon. Anatomy and description. In Pigs, Peccaries and Hippos (ed. W.R.L. Oliver), pp. 41-43. IUCN, Gland, Switzerland.

Homewood, K., Lambin, E.F., Coast, E., Kariuki, A., Kikula, I., Kivelia, J. et al. (2001) Long-term changes in Mara-Serengeti wildlife and land cover: pastoralists, population or policies? Proceedings of the National Academy of Science, 98, 12544-12549.

Karstad, E.L. (1984) The Ecology of Hippopotamus (Hippopotamus amphibius) in South-western Kenya. MSc thesis, University of Alberta, Edmonton, Canada.

Kenward, M.G. \& Roger, J.H. (1997) Small sample inference for fixed effects from restricted maximum likelihood. Biometrics, 53, 983-997.

Kenya Game Department (1953) Game Department Annual Report for 1951. Colony and Protectorate of Kenya Government Printer, Nairobi, Kenya.

Kimani, K. \& Pickard, J. (1998) Recent trends and implications of group ranch subdivision and fragmentation in Kajiado District, Kenya. Geographical Journal, 164, 202-213.

Kingdon, J.S. (1979) East African Mammals: An Atlas of Evolution in Africa. Volume 3, Part B: Large Mammals. Academic Press, London, UK.

KLingel, H. (1991) The social organization and behaviour of Hippopotamus amphibius. In African Wildife: Research and Management (eds I.B. Kayanja \& E.L. Edroma), pp. 73-75. ICSU, Paris, France.

LAmprey, R.H. \& REID, R.S. (2004) Expansion of human settlement in Kenya's Masai Mara: what future for pastoralism and wildlife? Journal of Biogeography, 31, 997-1032.

Laws, R.M. \& Clough, G. (1966) Observation on reproduction in the hippopotamus Hippopotamus amphibious. Symposium of the Zoological Society of London. 15, 117-140.

Lewison, R. \& Oliver, W. (2008) Hippopotamus amphibius. In IUCN Red List of Threatened Species v. 2010.4. Http://www. iucnredlist.org [accessed 4 November 2010].

Lock, J.M. (1972) The effects of hippopotamus grazing on grasslands. Journal of Ecology, 60, 445-467.

Marshall, P.J. \& Sayer, J.A. (1976) Population ecology and response to cropping of a hippopotamus population in eastern Zambia. Journal of Applied Ecology, 13, 391-402.

Mati, B.M., Mutie, S.M., Gadain, H. \& Home, P. (2005) Land cover change effects on flow regime. In Proceedings of the 2nd 
International ISCRAM Conference (eds B. Van de Walle \& B. Carle.), pp. 237-246. Brussels, Belgium.

Mukiny A, J.G. (1973) Density, distribution, population structure and social organization of the black rhinoceros in Masai Mara Reserve. East African Wildlife Journal, 11, 385-400.

Norton, P.M. (1988) Hippopotamus numbers in the Luangwa Valley, Zambia, in 1981. African Journal of Ecology, 26, 337-339.

Norton-Griffiths, M., Herlocker, D.J. \& Pennycuick, L. (1975) The patterns of rainfall in the Serengeti ecosystem. East African Wildlife Journal, 13, 347-374.

O’Connor, T.G. \& CAMp Bell, B.M. (1986) Hippopotamus habitat relationships on the Lundi River, Gonarezhou National Park, Zimbabwe. African Journal of Ecology, 24, 7-26.

Ogutu, J.O., Piepho, H.-P., Dublin, H.T., Bhola, N. \& Reid, R.S. (2007) El Nino-southern oscillation, rainfall, temperature and normalized difference vegetation fluctuations in the Mara-Serengeti ecosystem. African Journal of Ecology, 46, 132-143.

Ogutu, J.O., Piepho, H.-P., Dublin, H.T., Bhola, N. \& Reid, R.S. (2009) Dynamics of Mara-Serengeti ungulates in relation to land use changes. Journal of Zoology, 278, 1-14.

OKello, J.B.A., NyakaAna, S., Masembe, C., Siegismund, H.R. \& Arctander, P. (2005) Mitochondrial DNA variation of the common hippopotamus: evidence for a recent population expansion. Heredity, 95, 206-215.

Oliver, W.L.R. (ed.) (1993) Pigs, Peccaries and Hippos: Status Survey and Conservation Action Plan. IUCN, Gland, Switzerland.

Olivier, R.C.D. \& Laurie, W.A. (1974) Habitat utilization by hippopotamus in the Mara River. East African Wildlife Journal, 12, 249-271.

ONyeAnUSI, A.E. (1988) Large herbivore grass offtake in Masai Mara National Reserve: implication for the Serengeti-Mara migrants. Journal of Arid Environments, 16, 203-209.

Ottichilo, W.K., De Leeuw, J., Skidmore, A.K., Prins, H.H.T. \& SAID, M.Y. (2000) Population trends of large non-migratory wild herbivores and livestock in the Masai Mara ecosystem, Kenya, between 1977 and 1997. African Journal of Ecology, 38, 202216.

Owen-S mith, R.N. (1988) Megaherbivores: The Influence of Very Large Body Size on Ecology. Cambridge University Press, Cambridge, UK.

Petrides, G.A. \& Swank, W.G. (1965) Population densities and the range carrying capacity for large mammals in Queen Elizabeth National Park, Uganda. Zoologica Africana, 1, 209-225.

Reid, R.S., Rainy, M., Ogutu, J.O., Kruska, R.L., McCartney, M., Nyabenge, M. et al. (2003) People, Wildlife and Livestock in the Mara Ecosystem: Unpublished Report to International Livestock Research Institute, Nairobi, Kenya.

SAS Institute Inc. (2006) SAS System for Windows v. 9.1.3. SAS Institute Inc., Carey, USA.

SAyer, J.A. \& RAKHA, A.M. (1974) The age of puberty of the hippopotamus (Hippopotamus amphibius) in the Luangwa River in eastern Zambia. East African Wildlife Journal, 12, 227-232.

SerneEls, S., SAID, M.Y. \& LAMBin, E.F. (2001a) Impact of land use changes on the wildebeest migration in the northern part of the Serengeti-Mara ecosystem. Journal of Biogeography, 28, 391-407.

Serneels, S., SAid, M.Y. \& Lambin, E.F. (2001b) Land cover changes around a major East Africa wildlife reserve: the Mara ecosystem (Kenya). International Journal of Remote Sensing, 22, 3397-3420.

SinClair, A.R.E. \& ArCese, P. (1995) Serengeti in the context of worldwide conservation efforts. In Serengeti II: Dynamics, Management and Conservation of an Ecosystem (eds A.R.E. Sinclair \& P. Arcese), pp. 31-46. University of Chicago Press, Chicago, USA.
SMART, A.C. (1990) The density of Hippopotamus amphibious linnnaeus at Lake Naivasha, Kenya. Tropical Freshwater Biology, 2, 241-247.

Smuts, G.L. \& Whyte, I.J. (1981) Relationships between reproduction and environment in the hippopotamus (Hippopotamus amphibius) in the Kruger National Park. Koedoe, 24, 169-185.

Stelfox, J.G., Peden, D.G., Epp, H., Hudson, R.J., Mbugua, S.W., Agatsiva, J.L. \& Amuyunzu, C.L. (1986) Herbivore dynamics in southern Narok, Kenya. Journal of Wildlife Management, 50, 339-347.

Tадвот, L.M. \& Stewart, D.R.M. (1964) First wildlife census of the entire Serengeti-Mara region, East Africa. Journal of Wildlife Management, 28, 815-827.

TAWIRI (Tanzania Wildlife Research Institute) (2001) Total count of hippopotamus in Tanzania. Unpublished Report to Tanzania Wildlife Research Institute, Arusha, Tanzania.

Temio, A. (1987) Population status of the hippopotamus on the Luangwa River, Zambia. African Journal of Ecology, 25, 71-77.

Thornton, D.D. (1971) The effect of complete removal of hippopotamus on grassland in the Queen Elizabeth National Park, Uganda. East African Wildlife Journal, 9, 47-53.

Viljoen, P.C. (1980) Distribution and numbers of the hippopotamus in the Olifants and Blyde rivers. South African Journal of Wildlife Research, 10, 129-132.

Viljoen, P.C. (1995) Changes in the number and distribution of hippopotamus (Hippopotamus amphibius) in the Sabie River, Kruger National Park, during the 1992 drought. Koedoe, 38, 115-121.

Walpole, M.J., Morgan-Davies, M., Milledge, S., Bett, P. \& Leader-Williams, N. (2001) Population dynamics and future conservation of a free-ranging black rhinoceros (Diceros bicornis) population in Kenya. Biological Conservation, 99, 237-243.

Weiller, P., De-Meulennaer, T. \& Vanden-Block, A. (1994) Recent trends in the international trade of hippopotamus ivory. TRAFFIC Bulletin, 15, 47-49.

Western, D., Groom, R. \& Worden, J. (2009) The impact of subdivision and sedentarization of pastoral lands on wildlife in an African savannah ecosystem. Biological Conservation, 142, 25382546.

Williamson, D.F. (2004) Tackling the Ivories: The Status of the US Trade in Elephant and Hippo Ivory. Unpublished Report to WWF-TRAFFIC, Washington, DC, USA.

\section{Biographical sketches}

ERUSTUS KANGA is an ecologist with research interests in environmental conservation and management, climate change vulnerability assessments and mappings, and the links between species and ecosystems, especially the conservation and ecology of tropical forests and savannahs and their threatened species. JosePH OGUTU is an ecologist and statistical modeller with experience in modelling population dynamics of African herbivores. HAN OLFF's research interests are in plant-herbivore interactions, macroecology and biocomplexity, including the effects of herbivores on vegetation diversity and plant competition, feedbacks of vegetation characteristics on herbivore population and community processes, and biodiversity theory. Peter Santema is a biologist, currently studying stress hormones, reproduction and cooperative behaviour in meerkats. He has a keen interest in ornithology, with field experience working on the fairy-martin, the Seychelles warbler, blue tits, the purple-crowned fairy-wren and nightingales. 